\title{
Growth Performance and Survival Rate of Juvenile Catfish (Clarias gariepinus) Fed Processed Catfish Offal Diet"
}

\author{
${ }^{1}$ Iriobe, T. ${ }^{2}{ }^{2}$ Ajani, E.K., ${ }^{1}$ Ibrahim, R., ${ }^{1}$ Gana, A.B., and \\ ${ }^{3}$ Adegbite, M.A.
}
${ }^{1}$ Department of Forestry and Fisheries, Kebbi State University of Science and Technology, Kebbi State, Nigeria.
${ }^{2}$ Department of Fisheries Management, University of Ibadan, Oyo State, Nigeria. ${ }^{3}$ Department of Soil Science, Kebbi State University of Science and Technology, Kebbi State, Nigeria.

Article No.: 071818100

Type: Research

DOI: 10.15580/GJAS.2018.8.071818100

Submitted: 18/07/2018

Accepted: 14/08/2018

Published: $27 / 08 / 2018$

${ }^{\star}$ Corresponding Author Iriobe $T$.

E-mail: iriobetosin@gmail.com

Keywords: aquaculture, fish offal, Clarias gariepinus, fishmeal, protein
One of the major problems faced by aquaculture industry today is the high cost of fish feed and this contributes more than $50 \%$ of the total cost of production in intensification culture systems. An approach to reduce feed cost is by the substitution of fish meal with alternative cheaper protein sources like fish offal among others. Therefore, this experiment was carried out to evaluate the growth performance and survival of $C$. gariepinus juveniles fed with diets containing various percentages of fish offal to determine the optimum level of fish offal inclusion in diets of Clarias gariepinus. Five diets of T1(0\%), T2(20\%), T3(40\%), $\mathrm{T} 4(80 \%)$ and $\mathrm{T} 5(100 \%)$ levels of fish offal's substitutions were formulated to contain $40 \%$ crude protein and similar energy levels. The total of 150 juvenile fish was randomly distributed into three replicates of five experimental groups in a (45 x $35 \times 28 \mathrm{~cm}^{3}$ ) plastic rectangular container. Each replicate consist of 10 fish with a mean weight of $25 \mathrm{~g}$. At the end of the experiment, result showed that mean weight gain (MWG), survival rate (SR), protein intake (PI), protein efficiency ratio (PER), feed conversion ratio (FCR), specific growth rate (SGR) and relative growth rate of T0 were observed to be statistically $\mathrm{p}<0.05$ similar with $\mathrm{T} 1$ and $\mathrm{T} 2$. The study showed that diets with inclusion rate of $20 \%$ and $40 \%$ fish offal gave similar result as that fed with control diet. Therefore, fish offal with inclusion rate of $20 \%$ and $40 \%$ could be fed to $C$. gariapinus catfish without any negative effects on the growth and survival. 


\section{INTRODUCTION}

Aquaculture is one of the fastest growing food production sectors in the world and provides significant supplement and substitute to wild fishes (Adebayo and Quadri, 2005). Fisheries and aquaculture contribute significantly to food security and livelihoods. Fish provides essential nutrition for 3 billion people and at least $50 \%$ of animal protein and minerals to 400 million people from developing countries like Nigeria. Over 500 million people in developing countries depend, directly or indirectly, on fisheries and aquaculture for their livelihoods. Thus, aquaculture is the world's fastest growing food production system, growing at $7 \%$ annually and fish products are among the most widely traded foods, with more than 37\% (by volume) of world production traded internationally (FAO 2009).

One of the major problems faced by aquaculture industry today is the high cost of fish feed and this contributes more than $50 \%$ of the total cost of production in intensification culture systems (Ali et al,2005). This problem has been attributed to high cost of fish meal and irregular supply of conventional fish feed ingredients. An approach to reduce feed cost is by the substitution of fish meal with alternative cheaper protein sources. Another approach is to develop appropriate feeding management strategies to improve the utilization of feed. Omitoyin (2005) and Adeyemi et al. (2004) observed that majority of feed ingredients required for animal feeds can be met by using agroindustrial products, which are considered as wastes. The use of live organisms in aquaculture has for the past decades received tremendous attention in countries where aquaculture is well developed. Faturoti (2000) noted that for aquaculture industry to thrive apart from development of adequate man power there is also need to research and develop various inputs of production such as feed. The cost of feeding fish on artificial feed is very high only very few farmers can afford it, also artificial feed tends to pollute water as a result there is the need to find alternative feed for fish. In addition, Omitoyin (2005) reported that Nigeria aquaculture industry is currently faced with the problem of inadequate supply and prohibitive cost of quality fish feeds due to high and increasing demand of fish and animal protein. Therefore, the need for an alternative arises.

Over the years, researchers have embarked on studies to search for possible replacements to fish meal (Khan et al, 2003; Sotolu, 2010). The efficiency of the various alternatives protein sources as a partial or complete replacement for fish meal has been individually evaluated in fish diets. Fishmeal has been replaced by single animal protein source such as maggot meal (Adewolu, 2010), poultry by-product meal (Turker et al 2005), black soldier fly pupae meal (St Hilaire et al 2007), poultry viscera meal (Usman et al, 2007), and feather meal (Adewolu, 2010) among others. However, most of these single animal protein sources were unable to completely replace fishmeal (Adewolu, 2010) because of lack in one or more of the essential amino acids. Lysine, methionine and isoleusine are generally the limiting amino acids in animal sources of fishmeal alternatives (NRC, 1993). Therefore, suggested way of overcoming these deficiencies is by supplementary to obtain the desired essential amino acid profile (Ayoola, 2010).

The use of fish offal which it's composite include fish gut/intestine has been successfully used in fish nutrition to reduce cost of feeding. Tilapia offal has been reportedly used in aquaculture diets (Fagbenro and Jauncey, 1994) to feed fish. Hossain et al., (2003) replaced fishmeal with broiler offal in broiler diet at lowest feed cost per $\mathrm{kg}$ and observed a significant growth performance. More so, Lien and Ly (2001) reported that the use of fish silage with molasses could replace fishmeal in the diet for growing pigs. Fermented fish silage produced by addition of lactic acid, bacteria and a carbohydrate source was produced from Tilapia offal and subsequently used in aquaculture diets to feed fish (Fagbenro and Jauncey 1994) and significant growth performance was recorded. Therefore, this research was aimed at evaluating the growth performance and survival of Clarias gariepinus juveniles fed with diets containing various percentages of fish offal and also to determine the optimum level of fish offal inclusion in diets of Clarias gariepinus.

\section{MATERIALS AND METHODS}

\section{Collection and Acclimatization of Experimental fish}

The total of one hundred and fifty Clarias gariepinus juvenile Fish were purchased from a reputable fish farm, Ibadan, Oyo State, Nigeria with no history of pollution and diseases. The fish were sorted into uniform average size (25g) using a scoop net, sensitive weighing scale (Model: SK-1000, made by A\&D Company Limited, Korea) and were allotted randomly into 15 plastics tank with each tank having 10 juvenile fish. The fish were allowed to acclimate for fourteen days during this period they were fed on the control diet. At the end of the acclimatization period, fish were starved for 24 hours prior the commencement of the experiment to enable the fish emptied their guts after which initial weight of individual fish was taken.

\section{Experimental Diets}

Five experimental diets of $\mathrm{T} 1(0), \mathrm{T} 2(20 \%), \mathrm{T} 3(40 \%)$, $\mathrm{T} 4(80 \%)$ and $\mathrm{T} 5(100 \%)$ percentage level of inclusion of fish offal were formulated at $40 \%$ crude protein (Table 1). The ingredients used were maize, wheat offal, fishmeal, fish premix, vitamin C, dicalciumphosphate, fish oil methionine, lysine and fish offal. Fish offal of Clarias gariepinus was obtained from sacrificed Clarias gariepinus table sized fish. The gut content (intestine, kidney, liver, fish head etc) was removed with the aid of knife and hand. The extracted gut content was subjected to $50^{\circ} \mathrm{C}$ temperature for 10 hours until moisture and fat content was reduced and was sun dried. The dried offal was grinded into meal and combined with other composites of the experimental diets ingredients included in the fish feed 
at $20 \%, 40 \%, 80 \%$ and $100 \%$ respectively. The feed ingredients were grinded in a Hammer mill and mixed by a manual mixer with little water to form dough. The mixed ingredients were steam pelletized into 2 millimeter feed size. The diets were sun dried separately for 72 hours. Proximate analysis of the diets was done before they were fed to juvenile catfish (Clarias gariepinus). Proximate composition (dry matter, crude protein, crude fibre, ash, gross energy and lipid) was done following the method of AOAC (AOAC International, 2000). Crude protein was analysed for its $\mathrm{N}$ content (as $\mathrm{g} \mathrm{N} \times 6.25$ ) using the Kjedahl method (Gerhardt protein analyzer, United Kingdom) and amino acids concentration was determined using Amino Acid Analyzer (Biochrom, United Kingdom).

Fish offal (fish intestine, gills, egg, fat, blood) which are usually thrown away by fish processors because of its low economic value are readily available in fish processing centers at little or no cost attached it.

\section{Growth Calculation}

Growth and nutrient utilization were determined in terms of feed intake (FI), specific growth rate (SGR), feed conversion ratio (FCR), protein efficiency ratio (PER) and protein intake (PI) (Mondal et al., 2006):

FI = This was calculated by adding $5 \% \times$ weight of fish $x$ No of fish per tank in each treatment of the experiment period.

Mean Weight gain $(\mathrm{MWG})=(\mathrm{W} 2-\mathrm{W} 1)$

(Pitcher and Hart, 1982).

$\mathrm{W}=$ the mean final weight of fish 2

$\mathrm{W}=$ the initial mean weight of fish

Relative Growth rate (\%):

$$
\operatorname{RGR}(\%)=\frac{W f-W i}{W i} \times 100
$$

Where,

$\mathrm{Wi}=$ initial average weight $(\mathrm{g})$ at the beginning of experiment

$\mathrm{Wf}$ = final average weight $(\mathrm{g})$ at the end of experiment.

Specific Growth rate (\%): SGR $=\underline{100 \log (W 2-W 1)}$

(Brown, 1957).
Survival Rate: was calculated as follows:

Survival rate $(\%)=\underline{\text { Number of fish that survived }} \times 100$ Number of fish stocked

(Tegene et al., 2018).

Feed Conversion Ratio (FCR) $=\frac{\text { feed intake }(\mathrm{g})}{\text { Weight gain }(\mathrm{g})}$

(Wilson, 1989).

Protein Intake $=$ Protein content in the diet $x$ Daily

Feed Intake (Sveier et al., 2000).

Protein Efficiency Ratio (PER) = Mean Weight Gain

(Burel et al., 2000).

\section{RESULTS AND DISCUSSION}

Table 1: Proximate Composition of Fish Offal

Sample Identity Fish offal

Moisture (\%)

Crude protein(\%)

64.01

Crude lipid(\%)

10.95

Ash content (\%)

6.40

Crude fibre(\%)

1.21

Carbohydrate(\%)

2.05

\section{Amino acids}

$\begin{array}{ll}\text { Arginine } & 7.04 \\ \text { Histidine } & 2.14 \\ \text { Isoleucine } & 3.74 \\ \text { Leucine } & 7.63 \\ \text { Lysine } & 7.05 \\ \text { Methionine } & 9.80 \\ \text { Phenylalaline } & 3.18 \\ \text { Threonine } & 3.43 \\ \text { Valine } & 6.52 \\ \text { Tryptophan } & 7.04 \\ \text { Alanine } & 6.36 \\ \text { Serine } & 4.29 \\ \text { Proline } & 3.61 \\ \text { Valine } & 6.52 \\ \text { Aspartate } & 8.22 \\ \text { Glutamate } & 12.87 \\ \text { Tyrosine } & 2.37 \\ \text { Cystine } & 3.98\end{array}$

where; $W$ and $W$ the logarithms of initial $12=$ mean and final mean weights of fish, respectively, $\mathrm{T} 2-\mathrm{T} 1=$ Experimental period in day 
Table 2: Composition of experimental Diets

\begin{tabular}{llllll}
\hline \multicolumn{1}{c}{ Diet } & \multicolumn{5}{c}{ Percentage inclusion level of fish offal } \\
\hline Composition & T1 & T2 & T3 & T4 & T5 \\
\hline Maize (10\%) & 26.2 & 26.2 & 26.2 & 26.2 & 26.2 \\
Wheat offal (17\%) & 10.30 & 10.30 & 10.30 & 10.30 & 10.30 \\
Fishmeal (65\%) & 55.68 & 44.54 & 33.38 & 11.14 & 0 \\
Fish offal (64.01\%) & 0 & 11.14 & 22.27 & 44.54 & 55.68 \\
Fish premix & 0.75 & 0.75 & 0.75 & 0.75 & 0.75 \\
Vitamin C & 0.25 & 0.25 & 0.25 & 0.25 & 0.25 \\
Dicalcium phosphate & 0.5 & 0.5 & 0.5 & 0.5 & 0.5 \\
Fish oil & 6.0 & 6.0 & 6.0 & 6.0 & 6.0 \\
Methionine & 0.25 & 0.25 & 0.25 & 0.25 & 0.25 \\
Lysine & 0.25 & 0.25 & 0.25 & 0.25 & 0.25 \\
Total & 100 & 100 & 100 & 100 & 100 \\
& & & & & \\
Proximate Composition & & & & & \\
& & & & & \\
Crude protein, \% & 42.50 & 41.58 & 43.02 & 39.98 & 39.99 \\
Moisture \% & 9.75 & 9.60 & 9.80 & 9.70 & 9.71 \\
Crude fibre \% & 7.95 & 8.52 & 8.60 & 9.13 & 9.14 \\
Ash, \% & 3.18 & 3.24 & 3.09 & 2.95 & 3.17 \\
Crude lipid \% & 13.74 & 10.54 & 11.59 & 11.43 & 11.44 \\
Nitrogen Feed Extract & 19.01 & 22.06 & 19.19 & 22.86 & 22.86 \\
\hline
\end{tabular}

Table 3: Proximate composition of fish carcass before and after experiment

\begin{tabular}{lccccc}
\hline & Crude protein \% & Lipid\% & Ash\% & Crude fibre\% & Moisture\% \\
\hline Initial & 42.12 & 13.20 & 8.79 & 1.88 & 7.48 \\
\hline Final & & & & & \\
\hline T1 & 57.05 & 13.60 & 10.20 & 2.16 & 6.94 \\
T2 & 66.50 & 12.82 & 9.82 & 2.24 & 6.57 \\
T3 & 68.25 & 12.96 & 9.86 & 2.28 & 6.74 \\
T4 & 68.25 & 12.60 & 10.10 & 2.32 & 6.54 \\
T5 & 68.90 & 12.22 & 10.68 & 2.34 & 6.47 \\
\hline
\end{tabular}

Table 4: Growth and Feed Utilization of Clarias gariepinus catfish Juveniles

\begin{tabular}{|c|c|c|c|c|c|}
\hline Diet Parameters & T1 & T2 & T3 & T4 & T5 \\
\hline Initial weight $(\mathrm{g})$ & 25 & 25 & 25 & 25 & 25 \\
\hline Final weight $(\mathrm{g})$ & 80.51 & 79.94 & 72.61 & 48.27 & 37.67 \\
\hline Weight gain $(\mathrm{g})$ & 6.29 & 6.03 & 5.19 & 3.08 & 2.88 \\
\hline Mean weight gain $(\mathrm{g})$ & $11.04^{a}$ & $10.92^{a}$ & $9.51^{\mathrm{a}}$ & $4.60^{\mathrm{b}}$ & $2.50^{\mathrm{b}}$ \\
\hline Overall mean weight gain $(\mathrm{g})$ & $55.53^{a}$ & $54.60^{a}$ & $47.75^{\mathrm{a}}$ & $23.00^{b}$ & $12.49^{\mathrm{c}}$ \\
\hline No of fish/treatment & 30 & 30 & 30 & 30 & 30 \\
\hline Survival rate $(\%)$ & 93.33 & 96.67 & 83.33 & 76.33 & 73.33 \\
\hline Mortality rate (\%) & 6.6 & 3.33 & 16.67 & 26.26 & 23.33 \\
\hline Gross feed conversion efficiency (GFCE) & $41.5^{\mathrm{a}}$ & $41.0^{\mathrm{ab}}$ & $38.8 \mathrm{ab}$ & $29.8^{\mathrm{b}}$ & $15.1^{\mathrm{c}}$ \\
\hline Protein intake $(\mathrm{PI})$ & $10.83^{a}$ & $10.68^{a}$ & $9.98^{\mathrm{a}}$ & $6.58^{\mathrm{b}}$ & $6.37^{\mathrm{b}}$ \\
\hline Protein efficiency ratio (PER) & $1.033^{a}$ & $1.024^{\mathrm{a}}$ & 0.969 a & $0.743^{a}$ & $0.389^{\mathrm{b}}$ \\
\hline Feed conversion ratio (FCR) & $2.60^{a}$ & $2.52^{a}$ & $2.92^{a}$ & $4.23^{a}$ & $8.24^{b}$ \\
\hline Specific growth rate (SGR,\%) & $0.0071^{a}$ & $0.0071^{\mathrm{a}}$ & $0.0066^{a}$ & $0.0030^{\mathrm{b}}$ & $0.0025^{b}$ \\
\hline Relative growth rate (RGR) & $219.03^{a}$ & $215.27^{\mathrm{a}}$ & $189.67^{a}$ & $90.12^{b}$ & $49.61^{b}$ \\
\hline
\end{tabular}

N.B: means with the same alphabets are not significantly different from each other 
Table 5: Ranges and mean values of water quality parameters obtained during 10 weeks trial of Clarias gariepinus catfish juveniles

\begin{tabular}{lllllll}
\hline \multirow{2}{*}{$\begin{array}{l}\text { Experimental } \\
\text { diets }\end{array}$} & \multicolumn{2}{c}{ Temperature $\left({ }^{0} \mathbf{C}\right)$} & \multicolumn{2}{c}{$\mathbf{p H}$} & \multicolumn{2}{c}{ Dissolved oxygen(mg/l) } \\
\cline { 2 - 7 } & Range & Mean & Range & Mean & Range & Mean \\
\hline T1 & $26.0-27.5$ & 26.80 & $6.0-7.2$ & 6.60 & $4.00-5.50$ & 4.75 \\
T2 & $26.2-27.0$ & 26.60 & $6.5-6.8$ & 6.70 & $3.60-4.72$ & 4.16 \\
T3 & $25.9-27.5$ & 26.70 & $6.1-6.5$ & 6.30 & $3.50-5.85$ & 4.68 \\
T4 & $26.5-27.8$ & 26.80 & $6.76-6.90$ & 6.83 & $3.50-4.50$ & 3.75 \\
T5 & $27.0-27.8$ & 27.40 & $6.80-6.98$ & 6.88 & $3.50-4.80$ & 4.15 \\
\hline
\end{tabular}

The nutrient content of Fish offal (FO) was analysed for its proximate composition as observed from table 1. Result from table 1 showed that FO was found to have high crude protein (CP) $64.01 \%$ which is relatively similar to CP of fish meal $65 \%$. The proximate composition of fish offal (64.01) used to compound the experimental diets differed from

CP of $48.6-54.59 \%$ reported for some other fish offal meals (Farahiyah, et al., 2015; Tegene et al., 2018). FO was also observed to have a lipid content 10.95 , ash content of 6.4 , crude fibre of 1.21 and carbohydrate of 2.05. FO was further observed to be rich a source of amino acids. FO may vary in its nutritional quality depending on the source of its raw materials and also the processing method employed (Adewole and Olalaye, 2014)

\section{Experimental diets}

Five practical diets containing protein from Fish offal at different inclusion rate (T1, T2, T3, T4 and T5) were formulated and produced as shown in table 2. Diets with fish offal inclusion rate of T4\% and T5\% had the least crude protein, while diet with T3 inclusion rate had the highest crude protein. The crude protein contents of the experimental diets $(39.98-43.02 \%)$ were within the range recommended in $C$. gariepinus formulated test diets and it met the protein requirements (30 - 40\%) recommended as being optimum for growth in the C. gariepinus (Faturoti, 2000). Crude lipid were in the range of $10.64-13.74 \%$, while crude fibre were reported to be in the range of 7.95-9.14\% for the experimental diets.

Proximate composition of the carcass of the fish fed different levels of fish offal varied as shown in Table 3. Result showed that crude protein content of the fish carcasses were higher in the experimental fish $(57.05-68.90 \%)$ than in the pre-treatment fish $(42.12 \%)$. The result also showed that the protein content of the fish fingerlings fed T2, T3, T4 and T5 inclusion level of fish offal were higher than in the fishes fed at $\mathrm{T} 1$ inclusion rate.

The carcass lipids content of the experimental fishes varied slightly between $12.22-13.60 \%$ in the experimental diet which is also in the same range as that pre-treatment fish $(13.20 \%)$. Result obtained showed that carcass lipid was higher in pre-treatment fish than at inclusion levels of T2,T3,T4 and T5 except at $\mathrm{T} 1$ inclusion level.
Mean weight gain was significant at $p<0.05$ among the different fish offal inclusion rate as shown in table 4. The initial weight of fish used for the experiment was $25 \mathrm{~g}$. Result obtained showed that $\mathrm{T1}$, T2 and T3 showed the highest mean weight gained of $55.53 \mathrm{~g}, 54.60 \mathrm{~g}$ and $47.75 \mathrm{~g}$ which were not significantly different. Treatment levels with the highest mean weight gained (T1, T2 and T3) contained crude protein at $42.50 \%, 41.58$ and 43.02 respectively. This research shows that fish offal can replace fishmeal up to about $40 \%$ without any negative effect on growth. This is similar to the findings of Soltan et al. (2002) and Tegene et al., 2018 who stated that fish offal meal represented a good protein source due to its high content of the essential amino acids which can replace the conventional diets of $O$. niloticus.

Table 4 showed growth and feed utilization of catfish juvenile studied respectively. The growth and nutrient utilization being better at lower levels of inclusion $<40 \%$ than at higher levels. The control diet (T1) had the highest mean weight gain $(11.04 \mathrm{~g})$, while the least of $2.50 \mathrm{~g}$, were observed in fish fed $100 \%$ offal substitution $\mathrm{T} 4$.

Result in Table 4 further shows that SGR differ significantly at $p<0.05$ where $\mathrm{T} 1(0.0071), \mathrm{T} 2(0.0071)$ and T3(0.0066) were not significantly different, while the least SGR was observed at T5(0.0025). This result agrees with the findings of Farahiyah et al., 2015 who stated that commercial feed might contain compounds such as attractants to lure fish to consume more of the feed thus gaining weight, however the efficiency in converting the feed to meat and the efficiency of utilizing the protein content in the feed was not significantly different with fish fed with diet based on $100 \%$ fish offal meal inclusion.

Similarly, table 4 also showed that Clarias gariepinus juveniles fed with different diets were significant at $\mathrm{P}<0.05$ in terms of FCR. Fish fed with $\mathrm{T} 1(2.60)$, T2(2.52), T3(2.92) and T4(4.23) were not significantly different in terms, while the highest FCR was observed at $\mathrm{T} 5(8.24)$. Feed conversion ratio (FCR: feed per unit of body weight gain) is an important indicator of the quality of fish diets, a lower FCR indicate better utilization of the fish feed (Mary et al., 2015). According to a research by Tegene et al., 2018, fishes fed with soybean meal, poultry litter and fish offal had an FCR which were not significantly different from each other which may imply that the experimental diets had comparative nutritional value to control diet. FCR recorded in this research is similar to 
those reported by Tegene et al.,2018, Stickney and McGeachin 1984.

Furthermore, the protein efficiency ratio (PER) was significant at $\mathrm{p}<0.05$ in table 4 which shows that diet T1 showed the highest with PER (1.03) and diet $\mathrm{T} 4(0.389)$ had the lowest. Also there was decrease with increasing offal substitution. The mean PER for the fish fed with diets T1, T2, T3 and T4 were significantly not different, but significantly differ from those fed with the diet T4. In addition, the PER of all the fish fed in this experiment was observed not to be significantly different. This result suggests that protein sources other than fishmeal could be used to partially supplement for fish meal in fish diets. This result agrees with the findings of Adikwu and Haruna (1999) who observed similar growth performance of Clarias gariepinus fed with feather meal as a partial replacement of fish meal in diets.

RGR was significant at $p<0.05$ with $T 1, T 2$ andT3 observed not to be significantly different. While T4 showed the least RGR in table 4.

Table 4 also showed that PI was significant at $\mathrm{p}<0.05$ with diet T1, T2 and T3 observed not to be significantly different but differ significantly from $\mathrm{T} 4$ and T5. This result is similar to that obtained by Adewole, and Olaleye (2014) who reported that protein intake of control diet (commercial feed) was not significantly different from formulated diets.

Similarly, GFCE was significant at $p<0.05$, where diets T1, T2 and T3 are not significantly different, but differ significantly from T4 and T5 from table 4.

\section{CONCLUSION}

Fish offal can be used to replace fish meal partially in the diet of Clarias gariepinus, where fish farmers cannot afford the high cost of fish meal. The result of this study shows that fish offal can effectively replace fish meal to about $40 \%$. Fish offal is readily available and economical. The use of fish offal may allow greater flexibility in diet formulation without loss of fish performance. However, in order to avoid excessive deposition of feed in the tank, replacement of up to $40 \%$ is therefore recommended.

\section{REFERENCES}

Adebayo, O.T. and Quadri, I.C., (2005). Dietary protein level and Feeding rate for Hybrid Clarid Catfish, Clarias gariepinus $x$ Heterobranus bidorsallis in homestead tanks. Journal of Applied Aquaculture 17 (1): 97-106.

Adewole, H. A. and Olaleye, V. F (2014): Growth Performance in Clarias gariepinus Burchell Fingerlings Fed blood meal - bovine Rumen Digesta Blend Diets. Ife Journal of Science vol. 16, no. 3. Pp. 495-503.

Adewolu, M.A. and Adamson, A.A. (2011).Amaranthus spinosus leaf meal in the diet of Nile tilapia, Oreochromis niloticus. Pakistan Journal of Science and Industrial Research. 55:335-338.
Adewolu, M.A., N.B. Ikenweiwe and S.M. Mulero, (2010). Evaluation of an animal protein mixture as a replacement for fishmeal in practical diets for fingerlings of Clarias gariepinus. Isr. J. Aquacult. Bamidgeh, 62: 237-244.

Adeyemi., Ezeronye, Oboh (2004) Nutrient enrichment of cassava start industry by product.

Adikwu, I. A and. Haruna A. B. (1999). Nutritional Evaluation of Hydrolysed feather meal/plant protein blends as replacement for fishmeal protein in diets for juvenile Clarias gariepinus. African journal of Applied Zoology, vol. 2: 17 - 22 .

Ali, Z., Hossain. A. and Mazid A., (2005). Effect of mixed feeding schedules with varying dietary protein levels on the growth of sutchi catfish, pangasius hypiphthalmus (sauvage) with silver carp, Hypophthalmichthys molitrix (valenciennes) in ponds. Aquacult. Res., 36: 627- 634.

AOAC (Association of Official Analytical Chemist) (2000) Official methods of analysis, 17th edition.Association of Analytical Chemists, Gaithersburg, Maryland, USA.

Ayoola, S. O. (2010). Modern fish farming techniques (Aquaculture). Glamour books publishing company lbadan. 180pp.

Brown, M.E. (1957). The Physiology of Fishes, E4 Vol.1 Metabolism, vol. 2 Behaviour, Academic Press, New York.

Burel, C., Boujard, T., Tulli, F. and Kaushik, S. J. (2000). Digestibility of extruded peas, extruded lupin and rapeseed meal in rainbow trout (Oncorhynchus mykiss) and turbot (Psetta maxima) diets. Aquaculture 188: 285-298.

Fabgenro, O. A. \& Janucey, K. (1994c) Growth and protein utilization by juvenile catfish

(Clarias gariepinus) fed moist diets containing autoysed protein from stored lactic acid fermented fish silage. Biocresources Technology, 48: $43-48$.

Falaye ,E. A. (1998). Effects of maize bran diets on the growth and nutrient utilization of Tilapia (Oreochromis niloticus ). Nigerian association for Aquatic sciences selected papers from $9^{\text {th }} / 10^{\text {th }}$ Annual conference, Nigeria. pp 105-113.

Faturoti E. O., (2000) Review article on sustainable fisheries management through efficient fisheries resources data statistics: Journal of fisheries and Aquatic science, 6: 202-211.

FAO. (2009). The State of World Fisheries and Aquaculture. Annual conference In Rome. Updated in January 2010.pp 19-20.

Farahiyah, I. J., Wong, H.K., Zainal, A.A.R. and Ahmad, A. (2015) Fish offal meal as an alternative protein source of fish meal for Tilapia, Oreochromis sp. Mal. J. Anim. Sci. 18(2): 81-86

Hossain, M. H., Ahammad, M. U. and Howlider M. A. R. (2003). Replacement of fish meal by Broiler offal in Broiler Diet. International journal of poultry Science, 2(2): $159-163$.

Joshi P. K, Harish D, Bose M, (2002). Effect of under and malethione expose to certain blood parameters in a fresh water teleost fish Clarias batrachus. Pollution resources 21(1): 55- 57. 
Khan, M.N., Parveen M., Rab A., Afza M., Sahar V, Ali M.R. and. Naqvi S.M.H.M, (2003). Effect of replacement of fish meal by soybean and sunflower meal in the diet of Cyprinus carpio fingerlings. Pak. J. Biol. Sci., 6: 601-604.

Lien, Le Van and Le Viet. (2001). Replacing fishmeal on improved utilization of by-products for Animal feeding in Vietnam- NUFU project. Yutnam. p. 16.

Mary N Muchiri, Jackin N Nanua, David Liti (2015) A Comparative Study On Growth, Composition And Sensory Quality Between Farmed And Wild Nile Tilapia (Oreochromis niloticus). Net Journal of Agricultural Science 3(2): 56-61.

Massumotu, T., Ruchmat, T. and Ito, Y. (1996). Amino acid availability values for several protein sources for yellow tail (Seriola quinqueradiate). Aquaculture .146: 106- 119.

Mondal K., Kaviraj A., Mukhopadhyay P.K. (2006) Fish waste in urban and suburban markets of Kolkata: problems and potentials. Aquaculture Asia.11: 22-25.

NRC (National Research Council), (1993). Nutrient requirements of fish. National Academy Press, Washington, DC, 114pp.

Omitoyin, B. O. (2005). Problems and prospects of fish feed production In Nigeria. Invited Technical paper presented at USAID Aquaculture Marketing Stakeolder Forum Held at University of Ibadan conferences center on $13^{\text {th }}$ December 2005.pp 3.

Pitcher, T. J. and Hart, P. J. B. (1982). Fisheries Ecology. London \& Canberra: Croom Helm Ltd. (American edition): The Avi. Publ. Co., Inc., Westport, Conn. pp 414

Soltan MA, Radwan AA, Samra IM (2002) Effect of Varying Protein, Energy and Protein to Energy Ratio on Growth, Feed Efficiency and body composition of Nile Tilapia, Oreochromis niloticus. In The 1st Annual Conference on Aquaculture, December 2002. The Aquaculture Society. The Egyptian Society, Al-Aresh, p. 120.

Sotolu AO, (2010). Growth performance of clarias gariepinus (Bunchell, 1822) fed varying inclusions of Leucaena luecocephala leaf meal. Tropicultura, 28(3):168 - 172 .

Stickney RR, Mcgeachin RB (1984) Growth Food Conversion and Survival of Fingerling Tilapia Aurea Fed Differing Levels of Dietary Beef Tallow. Journal of Fish Culturists 46(2): 102-104.

St. Hilaire, S., Sheppard, C., Tomberline, J. K., Irving, S., Newton, L.,Mc Guire, M.A., Mosley, E.E., Hardy, R.W. and Sealey, W.(2007). Fly prepupae as a feedstuff for raindow trout, Oncorhynchus mykiss. Journal of the world Aquaculture society 38: 59- 67.

Sveier, H., Raae, A.J. and Lied, F. (2000). Growth and protein turn over in Atlantic salmon (Salmo salar); The effect of dieatary protein level and protein particle size. Aquaculture 185:10-120

Tegene Negesse, Sebsibe Amesa, and Yosef Teklegiorgis (2018). Replacing Soya Bean Meal with Fish Offal Meal and Poultry Litter in the Diets of Nile Tilapia (Oreochromis niloticus) Reared in Pond Culture on their Growth Performance and Carcass Composition. Agricultural Research and Technology, Open Research Journal. 14(3):1-9.

Turker A., Yigit M., Ergun S., Karaali B. and A. Erteken, (2005). Potential of poultry byproduct meal as a substitute for fishmeal in diets for Black Seaturbot Scophthalmus maeoticus: Growth and nutrient utilization in winter. Isr. J. Aquacult. - Bamidgeh , 57(1):49-61.

Usman R., Palingi N.N. and Ahmad T., (2007). Utilization of local feed ingredients in tiger grouper grow out moist diets. Aquacult. Asia Mag. , April pp 33-36.

Webster, C. D., Tidwell J. H., Goodgame L. S., Clark L. A., and Yancey D. H.. (1992). Winter feeding and growth of channel catfish of distillers grains with soluble as a total replacement of fish meal. J. Applied aquaculture, vol. 1(4): 1014.

Wilson, R.P. (1989). Amino acids and proteins. In: Fish Nutrition. (Halver, J.F. and Hardy, R.W. Eds) 3rd Edition. Academic Press Inc. Elsevier Science, Armsterdam. Pp 144-180. 